九州大学学術情報リポジトリ

Kyushu University Institutional Repository

\title{
Drainage Improvement Project : Cost and Benefit Analysis in the Mekong Delta, Vietnam
}

Khai, Huynh Viet

Laboratory of Environmental Economics, Department of Agricultural and Resource Economics, Faculty of Agriculture, Kyushu University I College of Economics, Can Tho University

Danh, Thanh Vo

Laboratory of Environmental Economics, Department of Agricultural and Resource Economics, Faculty of Agriculture, Kyushu University | College of Economics, Can Tho University

Duong, Vu Thuy

Laboratory of Environmental Economics, Department of Agricultural and Resource Economics, Faculty of Agriculture, Kyushu University | College of Economics, Can Tho University

Yabe, Mitsuyasu

Laboratory of Environmental Economics, Department of Agricultural and Resource Economics, Faculty of Agriculture, Kyushu University

https://doi.org/10.5109/1801781

出版情報：九州大学大学院農学研究院紀要. 62 (1)，pp. 189-195，2017-02-24. Faculty of Agriculture, Kyushu University

バージョン :

権利関係 : 


\title{
Drainage Improvement Project: Cost and Benefit Analysis in the Mekong Delta, Vietnam
}

\author{
Huynh Viet KHAI ${ }^{1}$, Vo Thanh DANH ${ }^{1}$, Vu Thuy DUONG ${ }^{1}$ and Mitsuyasu YABE* \\ Laboratory of Environmental Economics, Department of Agricultural and Resource Economics, \\ Faculty of Agriculture, Kyushu University, Fukuoka 812-8581, Japan \\ (Received October 20, 2016 and accepted November 4, 2016)
}

\begin{abstract}
The study used the approach of cost - benefit analysis (CBA) to assess the economic feasibility of the drainage improvement project in Chien Luoc hamlet, Can Tho City. The study has conducted face-to-face interviews of 60 households in the hamlet to estimate the economic loss of households due to flooding. Economic protection of loss is considered as the benefit of this project. The study showed that the annual economic loss of a household was around 12.35 million VND and total cost of the drainage improvement project was estimated about 153,819 USD, equivalent to 3.23 billion VND. CBA results showed that the net present value (NPV) of the project was estimated about 25.869 billion VND, 107\% for the internal return rate (IRR) and 9.7 times for the benefit-cost ratio (CBR) at the discount rate of $10 \%$. Therefore, the drainage improvement project in Chien Luoc hamlet was economically feasible and socially beneficial.
\end{abstract}

Key words: CBA, CBR, NPV, IRR

\section{INTRODUCTION}

According to Solomon et al. (2007), Vietnam is one of five countries that may be the most seriously affected by global climate change and a consequent rise in sea level (SLR). If the sea level rises by between 0.2 and 0.6 meters, 100-200 thousand ha of Vietnamese plains will be submerged. A one-meter rise would result in 0.3 to 0.5 million ha of the Red River Delta being submerged and $90 \%$ of the Mekong Delta would be flooded. The SLR scenarios released by the Ministry of Natural Resources and Environment (MONRE) in 2009 were constructed with two levels of environmental emergency in mind - a high level and a medium level. The results showed that compared to 1980-1999, on average, the SLR would measure between $30 \mathrm{~cm}$ and $33 \mathrm{~cm}$, and between $74 \mathrm{~cm}$ and $100 \mathrm{~cm}$ by the middle and at the end of this century, respectively (Danh and Khai, 2014).

Because Can Tho city is located in the downstream region of the Mekong River, namely Hau River, the city often bears the negative impacts caused by the weather. High tide associated with floods in the Hau River on heavily rainy days makes the water in the city increase rapidly. As a consequence, the city's drainage systems no longer afford drain all of the water, and inundation happens everywhere in the city that causes unexpected effects on the travel, daily living and health of the people. These problems require local authorities to find appropriate measures to solve them.

Chien Luoc, a hamlet in An Binh ward of Can Tho city, is one of regions where the drainage systems are unable to drain water not only in heavily rainy days but also in hight tide days. In Chien Luoc hamlet, flood usually happens in the annual rainy seasons from July to September. This could cause some serious health problems as well as environmental pollution, and also damage

${ }^{1}$ College of Economics, Can Tho University, Vietnam

* Corresponding author (E-mail: yabe@agr.kyushu-u.ac.jp) households' assets. Moreover, inundation could create unsavory smells and stagnant water for a long time, which is an essential environment for increasing dangerous bacteria and spreading many diseases such as dengue, cholera and so on. As a requirement of this urgent case, the project on "The drainage system improvement in Chien Luoc hamlet, An Binh ward, Ninh Kieu district, Can Tho city" has been conducted by the climate change coordination office of Can Tho city in collaborating with the office of urban management and people's committee of Ninh Kieu District, Can Tho City. This study applied the approach of cost-benefit analysis (CBA) to evaluate and expertise the economic feasibility of the drainage improvement project. The paper is structured as follows. The next section describes the situation of inundation and drainage system in the study area and introduces the theory of CBA. The following section reports the results of $\mathrm{CBA}$, including the estimation of the households' economic loss because of inundation, the discussions of cost and benefit measurement to assess the economic feasibility of drainage improvement project, and its sensitivity analysis.

\section{THE SITUATION OF FLOODING AND DRAINAGE CHANNEL}

Total area of Chien Luoc hamlet is 48.19 ha with 744 households and 3,344 people, including 1,597 males and 1,787 females. The population density in Chien Luoc is extremely high, at 6,939 people $/ \mathrm{km}^{2}$. Since the drainage channel in Chien Luoc has been narrowed, it could not afford to drain water in this region. Fifteen years ago, this channel was approximately $8-12$ meters in width. However, now its width is narrowed into only 1 -2 meters, and about $2 \mathrm{~km}$ in length. Many sections of the channel have been leveled for building houses, roads. Thus, the channel could not be capable enough for drainage in the flooding seasons and inundation appears everywhere in this region during the rainy seasons and 
the high tide days.

According to the result of a survey in 2015, the average inundation time of the 3 months period is around 14 days, the maximum value is 30 days and the minimum value is 9 days. In rainy seasons, people usually use some ways such as slapping water, creating grooves for drainage, pumping water out to avoid inundation. Flooding often carries a large amount of waste and dirt, so people have to spend about 1 to 2 hours to clean their houses, yards and so on. Flooding has a huge negative influence on local people. They have to spend a lot of money to fix the damages caused by flooding such as repairing roads, floors, walls and so on. Inundation also brings the community many difficulties in travel and daily life, while stagnant water could cause health problems and dangerous diseases, especially for the elderly and children.

\section{COST - BENEFIT ANALYSIS METHOD}

Like other countries, the approach of CBA is commonly used in the evaluation and assessment of public projects in Vietnam. Tuan et al. (2015) estimated the cost and benefit of storm resistant housing in Da Nang, Vietnam. In this study, the economic feasibility of storm resistant housing was analyzed in two scenarios: with and without climate change. The results showed the net present value (NPV) was 3,290.31 USD and $4,803.39$ USD, the internal rate of return (IRR) was $14 \%$ and $20 \%$, the ratio of benefit - cost was estimated around 1.93 and 2.36 in the former and the later scenario, respectively. In both two these cases, the project was economically feasible. CBA method was also used in the research by Tinh et al. (2013) to compare the economic feasibility between mangrove forest restoration and aquaculture projects in Thi Nai Lake, Binh Đinh province. Within the period of 22 years, total benefit of mangrove forest restoration project was estimated about 21 billion VND whereas this figure in aquaculture project was only 10 billion VND. Moreover, with an increase in frequency and intensity of risks associated to climate change and sea level rise, mangrove restoration could create much more social benefits in the current condition. Therefore, mangrove restoration should be encouraged to implicate and be the optimal choice for wetland conservation.

Danh and Khai (2014) applied the risk CBA framework to assess the dike options proposed for Vietnamese Mekong River Delta. There were three cost components in the cost category: construction costs, maintenance costs, and dike heightening costs. The benefit category was defined as economic damage avoided in the VMD because of the protection offered by the dike system. The results showed that applying option 4 to the entire length of the dike system $(147 \mathrm{~km})$ incurred the highest present value (PV) of USD 666.5 million. Option 1 had the lowest PV costs, at USD 361.9 million. Following the CBA framework, sensitivity analyses of negative changes in discount rates and salinity impacts were conducted to assess the robustness of the projected dike options.
First, the results showed that the expected net present values of dike options were very sensitive to changes in discount rate. Second, if the salinity-protected area is $50 \%$ of the total land area, the CBA results were not significantly altered.

The project's welfare changes could be calculated by comparing between the benefits and costs of project (Sartori, 2014). The approach of CBA is considered as a useful tool to assess the economic feasibility of a specific project, a policy or a program by monetizing the nonmarket and market values of all project costs and benefits which are useful information for decision makers. The basic financial indicators in CBA were used to assess the feasibility of project as follows:

- Net Present Value (NPV) is popularly used to reflect the net benefit of a project. NPV is the result of the subtraction between total benefits and costs after they are discounted by a specified rate of return and defined as a value of money after these benefits are discounted into the first year of the project life circle. The project will be economically feasible if the NPV is positive or the optimal choice is the project with the biggest value of NPV among alternative projects.

$$
N P V=P V B-P V C=\sum_{t=0}^{n} \frac{B_{t}-C_{t}}{(1+r)^{t}}
$$

$$
\text { where } P V B=\sum_{t=0}^{n} \frac{B_{t}}{(1+r)^{t}} \text { and } P V C=\sum_{t=0}^{n} \frac{C_{t}}{(1+r)^{t}} \text { is the }
$$

present value of the project benefits and costs, respectively; Bt and $\mathrm{Ct}$ is the benefits and costs of the project in year $t$; and $r$ is discount rate.

- Benefit-Cost Ratio (BCR): The BCR is a variant of the NPV, with the benefits divided by the costs. If the ratio is greater than 1 , a project is considered to add value to society.

$$
B C R=\frac{\sum_{t=0}^{n}\left(\frac{B_{t}}{(1+r)^{t}}\right)}{\sum_{t=0}^{n}\left(\frac{C_{t}}{(1+r)^{t}}\right)}
$$

where $B C R$ is Benefit Cost Ratio (this ratio indicates the amount of money (benefits) can be created from spending the project cost of 1 VND). The project will be feasible if the value of $\mathrm{BCR}>1$. The higher the ratio, the greater the benefits created from the costs. Among alternative projects, the optimal choice is the project with the biggest value of BCR.

- Internal Rate of Return (IRR): whereas NPV and BCR use a fixed discount rate, this criterion calculates the interest rate internally. This represents the return on investment in the project. A project is rated desirable if the IRR surpasses the average return of public capital as determined beforehand. The IRR is calculated by two below formulas:

$$
\sum_{t=0}^{n}\left(\frac{B_{t}-C_{t}}{(1+I R R)^{t}}\right)=0 \text { or } \sum_{t=0}^{n} \frac{B_{t}}{(1+I R R)^{t}}=\sum_{t=0}^{n} \frac{C_{t}}{(1+I R R)^{t}}
$$

The primary data for this CBA study were randomly collected by face-to-face interviewing 60 households in 
Chien Luoc hamlet, Can Tho city. The content of the questionnaire includes the demographic information, perceptions of respondents about the inundation and information on economic losses (e.g. the cost of house asset repairs, the cost of road and house repairs, medical expenses) that households were suffering due to inundation.

\section{RESULTS AND DISCUSSION}

\section{Description of respondents' information}

The information of gender, education level and average income of respondents are presented in Table 1. Among 60 interviewees, female respondents are accounted for $58.3 \%$, higher than male one (41.7\%). The highest percentage of respondents (43.3\%) obtains the level of secondary education, following by the primary education level of $33.3 \%$. The results show that the average household income is about 5.6 million VND per month with the most frequent category of below VND 3 million (30\%), followed by 3 million - 5 million VND and 5 million -7 million VND (about $20 \%$ of each).

Table 1. Gender, education level and household income of respondents

\begin{tabular}{lcc}
\hline Items & Frequency & Percentage (\%) \\
\hline Gender & $\mathbf{6 0}$ & $\mathbf{1 0 0 . 0}$ \\
- Male & 25 & 41.7 \\
- Female & 35 & 58.3 \\
\hline Education level & $\mathbf{6 0}$ & $\mathbf{1 0 0 . 0}$ \\
- Primary school & 20 & 33.3 \\
- Secondary school & 26 & 43.3 \\
- High school & 7 & 11.7 \\
- College & 3 & 5.0 \\
- Undergraduate & 4 & 6.7 \\
- Postgraduate & 0 & 0 \\
\hline Income (millions VND) & $\mathbf{6 0}$ & $\mathbf{1 0 0 . 0}$ \\
- Under 3 millions & 18 & 30.0 \\
- From 3 to 5 millions & 12 & 20.0 \\
- From 5 to 7 millions & 12 & 20.0 \\
- From 7 to 9 millions & 9 & 15.0 \\
- From 9 to 11 millions & 4 & 6.7 \\
- From 11 to 13 millions & 2 & 3.3 \\
- From 13 to 15 millions & 2 & \\
- Over 15 millions & 1 & \\
\hline
\end{tabular}

Source: Surveyed in 2015

Table 2 illustrates information about the respondent's age and family size. The average age of respondents is rather high, at approximately 47 years old. The youngest respondent is 20 years old and the oldest is 84 years old. In this survey, the collected data is related to household's economic loss and problems caused by flooding, so respondents in these ages could provide reliable information. The average number of family member is about 5 persons with the children number of 1.3 and the adult of 3.8 persons.

Table 2. Age and family size of respondents

\begin{tabular}{lrccc}
\hline Items & Mean & $\begin{array}{c}\text { Standard } \\
\text { Deviation }\end{array}$ & Minimum & Maximum \\
\hline Age & 47.15 & 12.77 & 20 & 84 \\
Number of members & 5.13 & 3.02 & 1 & 21 \\
$\quad$ - Children $(<18)$ & 1.33 & 1.43 & 0 & 9 \\
- Adult $(>=18)$ & 3.80 & 1.95 & 1 & 12 \\
\hline
\end{tabular}

Source: Surveyed in 2015

Information on respondents' occupation is represented in Figure 1. The highest rate of respondents' job is the housewife (37\%), followed by the worker and carpenter (about 25\%), the small-scale trader (around $13 \%$ ) and other jobs such as the teacher, tailor, hodman, retirement, unemployment (about 17\%).

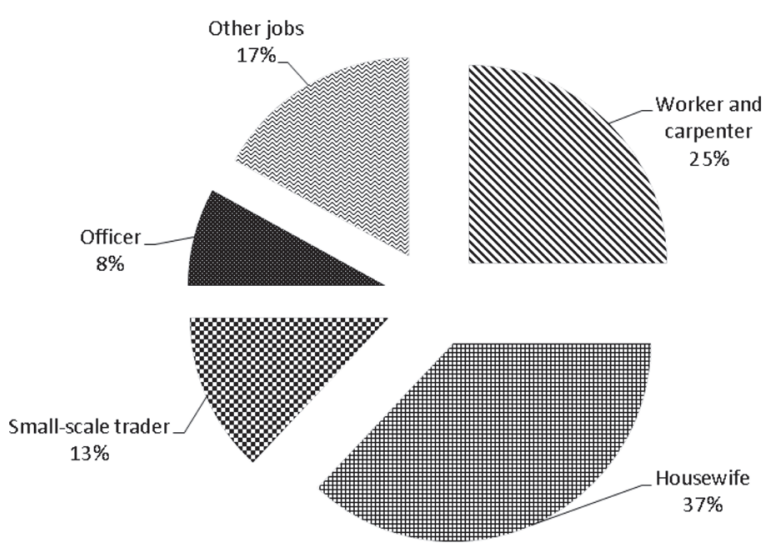

Fig. 1. Percentage of respondent's occupation $(\mathrm{n}=60)$. Source: Surveyed in 2015

\section{Identifying the cost of the project}

Total cost of the project is presented in Table 3, including the cost for study on project feasibility, the cost of monitor, the cost of project planning, and the cost of drainage construction.

Total cost of the project in 2014 is 869 million VND, including the cost for study on project feasibility, the cost of monitor and project planning, while total cost of the project in 2015 is about 2.39 billion VND, including the cost of monitor ( 0.17 billion VND) and the cost of drainage dredging and improvement (2.23 billion VND). There is only the cost of monitor of 165 million VND in 2016. After 2016, the project will be allocated the right of the drainage management to local households and authorities. An annual maintenance cost (e.g. garbage collection) is estimated about 20 million VND (100 working days * $200.000 \mathrm{VND} /$ day) and this could be assigned for local households.

\section{Identifying the benefits of project}

In case of the project of disaster risk reduction, the benefits are considered as the damage reduced or avoided (Tuan et al., 2015). The benefits of the drain- 
Table 3. Cost items of the project

\begin{tabular}{lccrrrr}
\hline \multirow{2}{*}{ Cost } & \multicolumn{2}{c}{$\mathbf{2 0 1 4}$} & \multicolumn{2}{c}{$\mathbf{2 0 1 5}$} & \multicolumn{2}{c}{$\mathbf{2 0 1 6}$} \\
\cline { 2 - 7 } & USD & \multicolumn{1}{c}{ VND } & USD & VND & USD & \multicolumn{1}{c}{ VND } \\
\hline Study on project feasibility & 14,130 & $314,957,700$ & - & - & - & - \\
Monitor & 14,819 & $330,315,510$ & 7,410 & $165,168,900$ & 7,410 & $165,168,900$ \\
Project planning & 10,026 & $223,479,540$ & - & - & - & - \\
Drainage construction & - & - & 100,024 & $2,229,534,960$ & - & - \\
Total & $\mathbf{3 8 , 9 7 5}$ & $\mathbf{8 6 8 , 7 5 2 , 7 5 0}$ & $\mathbf{1 0 7 , 4 3 4}$ & $\mathbf{2 , 3 9 4 , 7 0 3 , 8 6 0}$ & $\mathbf{7 , 4 1 0}$ & $\mathbf{1 6 5 , 1 6 8 , 9 0 0}$ \\
\hline
\end{tabular}

Note: Exchange rate is 22,290 VND/USD in 10/10/2015

Source: Climate change coordination office of Can Tho City, 2014

age canal improvement project are defined as the damage avoided in terms of the present of the project, showing in Table 4.

The damage of the households due to flooding includes the damage of road, buildings, equipment and furniture, the medical cost, the cleanup cost, an increase in utility cost, and the cost of disease prevention. Total average damage per household due to flooding was estimated by totaling all the reported costs across each of the categories for all survey respondents, divided by the number of respondents. The average damage of a household caused by flooding is about 12.35 million VND per household per year. According to the report provided by local authorities, 460 households living along the drainage could receive the benefits of the project, so total benefits of the project could be estimated around 5.68 billion VND per year (12.35 million VND * 460 households).

Because households have to pay by themselves to prepare their paths, walkways and parking after the flooding period, those costs incurred due to flooding are estimated about 2.84 million per household every year.

Table 4. The annual benefits of the project

\begin{tabular}{lc}
\hline The cost items (damage avoided) & $\begin{array}{c}\text { Average cost (Million } \\
\text { VND/household) }\end{array}$ \\
\hline The prepare costs of paths, walkways and parking & $\mathbf{2 . 8 4}$ \\
The damage of buildings & $\mathbf{7 . 9 4}$ \\
- Cost of raising floor level & 7.77 \\
- Cost of house repair & 0.17 \\
The damage of equipment and furniture & $\mathbf{0 . 5 1}$ \\
- Cost of TV repair & 0.04 \\
- Cost of refrigerator repair & 0.06 \\
- Cost of VCD player repair & 0.05 \\
- Cost of motorbike repair & 0.02 \\
- Cost of replacing tables and chairs & 0.34 \\
Health cost & $\mathbf{0 . 7 3}$ \\
- Cost of medicines and medical treatment & 0.40 \\
- Cost of hospitalization & 0.25 \\
- Cost of time off work to care for the sick & 0.08 \\
Cleanup cost & $\mathbf{0 . 0 2}$ \\
An increase in the cost of electricity and water & $\mathbf{0 . 0 6}$ \\
Prevention cost & $\mathbf{0 . 2 5}$ \\
- Cost of buying mosquito coil & 0.06 \\
- Cost of buying mosquito spray & 0.12 \\
- Cost of buying mosquito racket & 0.01 \\
- Cost of buying lime & 0.01 \\
- Cost of buying water pumps & 0.04 \\
\hline
\end{tabular}

Source: Surveyed in 2015 
The building damage of 7.94 million VND per household composes the costs of raising floor level (7.77 million VND per household) ${ }^{1}$ and house repair ( 0.17 million per household). Although the cost of raising floor level is already spent and not avoided if the present of the project, this cost will be generated again in the future if the absent of the project. Thus, the study also includes this cost to be considered as a sunk cost avoided or the benefit of the project. The average cost of health is calculated 0.73 million per household annually, including the cost of medicine and medical treatment, hospital cost and the cost of time off work to care for the sick (workdays lost due to the care of patient). On average, the cleanup cost is about 0.02 million VND and 0.06 million VND per household for an increase in electricity and water use due to flooding, while the average cost of prevention is estimated about 0.25 million VND, including the cost of purchasing mosquito coil, mosquito spray, mosquito racket, lime, water pumps and pipes.

\section{Cost - benefit analysis}

In economic calculations, future benefits are discounted in relation to current benefits to reflect the cost of capital. This is justified on the assumption that the current value of future benefits from investments should be compared to existing, secure investment alternatives for the same funds. Applying high discount rates expresses a strong preference for the present while potentially shifting large burdens to future generations. A discount rate of $10-12 \%$ is often assumed as a standard practice in developing countries (Tuan et al., 2015). As widely cited in existing CBA literature related to envi- ronmental projects in Vietnam (Tuan et al., 2015; Tinh et al., 2013; Truong, 2011; Tuan and Navrud, 2008), the discount rate of $10 \%$ is used as a common base for this study and the annual benefit of 5.681 billion VND is the same during the life circle of the project.

Table 5 shows the results of cost - benefit analysis of the project. Because this project is categorized as a development project and based on the suggestions given by experts in the climate change coordination office of Can Tho city, the lifetime of the project is assumed 10 years and the benefits of the project are evaluated in 10 years from 2016 to 2025. Total cost and benefit of the project are approximately 3.609 billion VND (including the annual maintenance cost of 20 million VND from the year of 2017) and 56.810 billion VND, respectively. The project takes the year of 2013 as a base year, so the present values from 2014 to 2025 are referred to those in 2013 and the discount value is calculated at the end of year. Total present values of costs and benefits are equivalent to 2.980 billion VND and 28.849 billion VND, respectively.

The results show that the net present value (NPV) of the project is 25.869 billion VND (greater than zero) and the benefit- cost ratio (BCR) of 9.7 at the discount rate of $10 \%$, showing that the project investment of 1 VND could receive about the benefit of $9.7 \mathrm{VND}$. Moreover, the internal return rate (IRR) of $107 \%$ is much higher than the discount rate of $10 \%$, revealing that the project is highly potential for investments. Overall, the values of NPV, BCR and IRR show that the project brings economic benefits to the local society.

Table5. Cost-benefit analysis of the drainage improvement project

\begin{tabular}{rrrrrrr}
\hline Year & $\begin{array}{r}\text { Total cost } \\
\text { (VND 1000) }\end{array}$ & $\begin{array}{r}\text { Total benefit } \\
\text { (VND 1000) }\end{array}$ & $\begin{array}{r}\text { Discount } \\
\text { rate } \\
(\mathbf{1 0 \%})\end{array}$ & $\begin{array}{r}\text { Present value } \\
\text { of benefit } \\
\text { (VND 1000) }\end{array}$ & $\begin{array}{r}\text { Present value } \\
\text { of cost } \\
\text { (VND 1000) }\end{array}$ & $\begin{array}{r}\text { Net present } \\
\text { value }\end{array}$ \\
\hline 2014 & 868,753 & & 0.91 & & 789,775 & $(789,775)$ \\
2015 & $2,394,704$ & & 0.83 & & $1,979,094$ & $(1,979,094)$ \\
2016 & 165,169 & $5,681,000$ & 0.75 & $4,268,219$ & 124,094 & $4,144,126$ \\
2017 & 20,000 & $5,681,000$ & 0.68 & $3,880,199$ & 13,660 & $3,866,539$ \\
2018 & 20,000 & $5,681,000$ & 0.62 & $3,527,454$ & 12,418 & $3,515,036$ \\
2019 & 20,000 & $5,681,000$ & 0.56 & $3,206,776$ & 11,289 & $3,195,487$ \\
2020 & 20,000 & $5,681,000$ & 0.51 & $2,915,251$ & 10,263 & $2,904,988$ \\
2021 & 20,000 & $5,681,000$ & 0.47 & $2,650,228$ & 9,330 & $2,640,898$ \\
2022 & 20,000 & $5,681,000$ & 0.42 & $2,409,299$ & 8,482 & $2,400,817$ \\
2023 & 20,000 & $5,681,000$ & 0.39 & $2,190,271$ & 7,711 & $2,182,561$ \\
2024 & 20,000 & $5,681,000$ & 0.35 & $1,991,156$ & 7,010 & $1,984,146$ \\
2025 & 20,000 & $5,681,000$ & 0.32 & $1,810,142$ & 6,373 & $1,803,769$ \\
\hline Total & $\mathbf{3 , 6 0 8 , 6 2 6}$ & $\mathbf{5 6 , 8 1 0 , 0 0 0}$ & & $\mathbf{2 8 , 8 4 8 , 9 9 7}$ & $\mathbf{2 , 9 7 9 , 5 0 0}$ & $\mathbf{2 5 , 8 6 9 , 4 9 7}$ \\
\hline & NPV & & & & $25,869,497$ \\
& IRR & BCR & & & & $107 \%$ \\
& & & & & 9.7 \\
\hline
\end{tabular}

Source: Surveyed in 2015

There are 26 households within the sample who actually have invested in raising their flood level with total cost of 466 million VND. The average cost of raising floor level was estimated by dividing the total flood level-raising cost of 26 respondents by 60 samples. 


\section{Sensitivity analysis \\ The change of discount rate}

The environment projects are often sensitive to the discount rate. The economic indicators of NPV, IRR and BCR are estimated again to analyze the economically potential investment of the project if the discount rate changes. In this study, the discount rate of $10 \%$ is used as the base rate and the discount rates of 5\%,15\% and $20 \%$ are used to analyze the sensitivity of the project. The discount rate of $5 \%$ is chosen to consider the project in the long term and the discount rates of $15 \%$ and $20 \%$ are used to represent the context of the economic crisis.

Table 6 shows that even if the economy is in crisis and the discount rates of $15 \%$ and $20 \%$ are applied, the drainage improvement project still has the high value of IRR and the big value of BCR. At the discount rate of $5 \%$, the values of IRR, NPV and BCR are also high. Therefore, we could conclude that the project is economically attractive under a wide range of plausible economic conditions and discount rates.

\section{The change of project benefit}

The results of study show that the greatest damage due to flooding is the cost of raising floor level which is considered as the avoided cost of the project. The question is whether or not the project remains economically attractive if this cost is excluded. Total annual benefit of the project is about 2.107 billion VND (5.681 billion VND - 3.574 billion VND) without the raising floor level cost of 3.574 billion VND (7.77 million VND * 460 households),

Table 7 shows the results of cost-benefit analysis in the absence of floor upgrade cost. The results show when the cost of floor upgrade is not counted into the benefit of the project, the values of NPV, IRR and BCR reveal that the project still has positive economic benefits at the discount rate of $10 \%$.

\section{The change of project life circle}

At the end of the project, the management, protection and maintenance of the drainage improvement project are transferred to local households and authorities in the project area, so if the local households and authorities have reasonable measurements to manage the drainage, the life circle of project could increase. The results of sensitivity analysis on lifetime change are presented in Table 8.

Table 6. Sensitivity analysis on the change of discount rate

\begin{tabular}{lcrrrr}
\hline \multirow{2}{*}{ Index } & Unit & \multicolumn{4}{c}{ Discount rate (\%) } \\
\cline { 3 - 6 } & & $\mathbf{5 \%}$ & $\mathbf{1 0 \%}$ & $\mathbf{1 5 \%}$ & $\mathbf{2 0 \%}$ \\
\hline NPV & VND 1000 & $36,523,892$ & $25,869,497$ & $18,821,358$ & $14,010,697$ \\
IRR & $\%$ & $117 \%$ & $107 \%$ & $98 \%$ & $90 \%$ \\
BCR & Time & 12.2 & 9.7 & 7.9 & 6.5 \\
\hline
\end{tabular}

Source: Surveyed in 2015

Table7. Sensitivity analysis on the change of project benefit

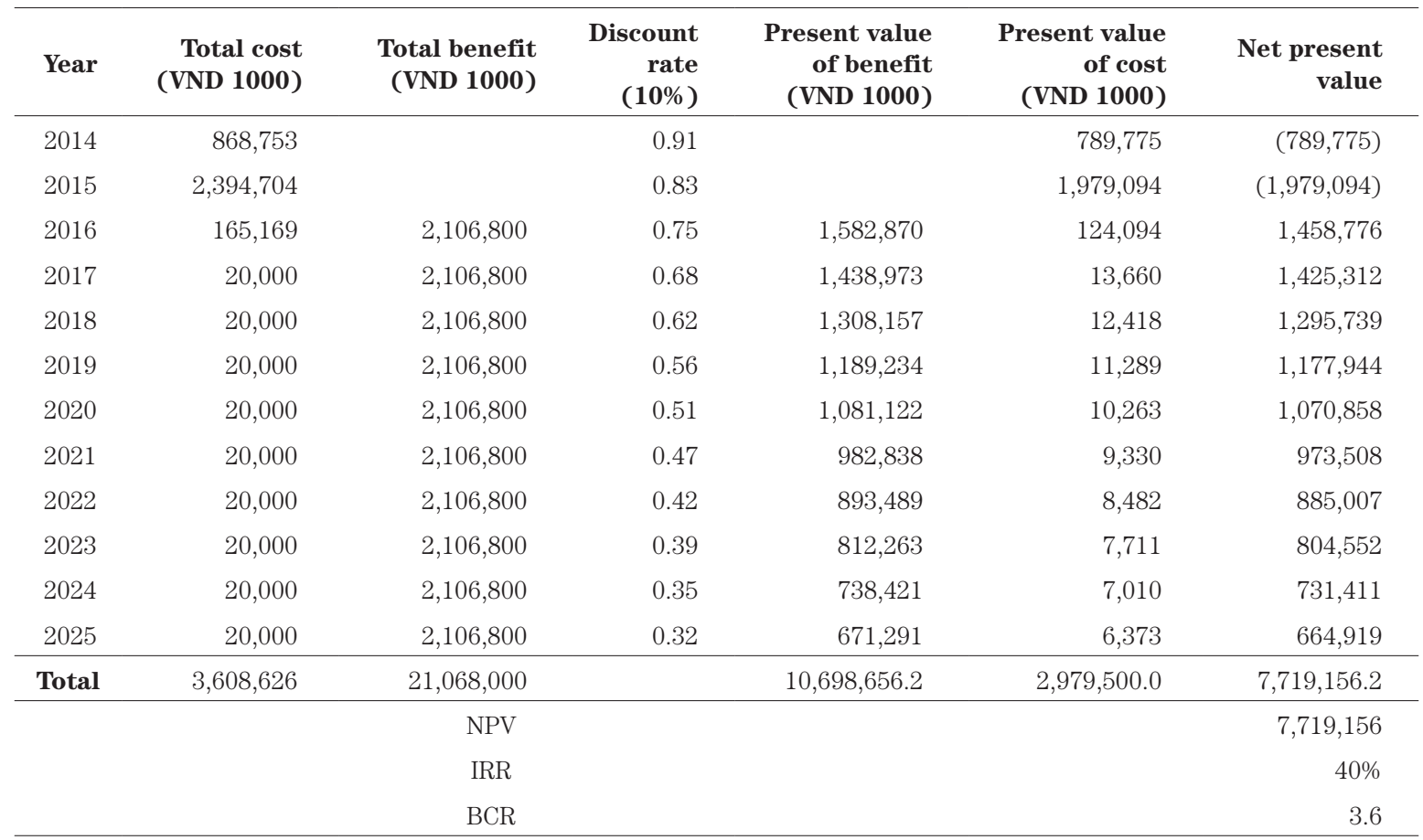


Table 8. Sensitivity analysis on the change of project life circle

\begin{tabular}{lcrrr}
\hline \multirow{2}{*}{ Index } & \multirow{2}{*}{ Unit } & \multicolumn{3}{c}{ The life circle of project } \\
\cline { 3 - 5 } & & 10 years & 15 years & 20 years \\
\hline NPV & VND 1000 & $25,869,496.5$ & $32,707,200.4$ & $36,952,876.5$ \\
IRR & $\%$ & $107 \%$ & $107 \%$ & $107 \%$ \\
BCR & Time & 9.7 & 11.9 & 13.2 \\
\hline
\end{tabular}

Note: Discount rate of $10 \%$.

Source: Surveyed in 2015

The results show that the project is more economically attractive when the lifetime of the project increases. In particular, the NPV value is 32.707 billion VND if the lifetime of the project increases by 15 years and 36.952 billion VND by 20 years while the BCR value is about 11.9 times for the lifetime project of 15 years and 13.2 times for 20 years.

\section{CONCLUSION}

The drainage improvement project with a total investment cost of $\$ 153,819$ (3.43 billion VND) included the grant of $\$ 119,071$ (2.65 billion VND), accounted for $77.41 \%$ and the local counterpart fund of $\$ 34,748$ USD (0.77 billion), accounted for $22.49 \%$ of total project investment. The study has employed the approach of CBA to assess the economically potential feasibility of the project. The results showed the project generated net economic benefits and beneficial to the society. In particular, the NPV value of the project at a discount rate of $10 \%$ was estimated about 25.869 billion $\mathrm{VND}$, the IRR value of $107 \%$ much larger than the base discount rate of $10 \%$ and the large BCR value of 9.7 times.

Sensitivity analysis examines the economically potential investment of the project when the initial assumptions change. In this study, the change of discount rate and benefit (damage avoided) were assumed in the sensitivity analysis. The changing discount rates of $5 \%, 15 \%$ and $20 \%$ were used to assess the economically potential investment of the project. The results showed that the project was still sociably beneficial at the discount rate of $5 \%, 15 \%$ and $20 \%$. When the cost of raising floor level was excluded in the benefits, the project with the NPV value of 3.604 billion VND was still economically attractive at a discount rate of $10 \%$. Moreover, the project lifetime varies from 10 years to
15 years and 20 years, the estimated values of NPV, IRR and BCR showed the project more economically potential for investments. In summary, the drainage improvement project in Chien Luoc hamlet brings economic benefits to the society.

\section{ACKNOWLEDGMENTS}

We would like to express our gratitude to The Rockefeller Foundation for sponsoring the study under the project "Community-based Urban Flood and Erosion Management for Can Tho city", as part of the Asian Cities Climate Change Resilience Network. Our warmest thanks go to Dr. Nguyen Ngoc Huy and Dr. Stephen Tyler from Institute for Social and Environmental Transition for their constructive comments and suggestions, and we are extremely grateful to Mr. Ky Minh Chau in CCCO Can Tho for assisting in data collection.

\section{REFERENCES}

Danh, V.T and H.V, Khai. 2014 Using a Risk Cost-Benefit Analysis for a Sea Dike to Adapt to the sea Level in the Vietnamese Mekong River Delta. Climate, 2: 78-102

Ministry of Natural Resources and Environment 2009 Climate Change, Sea Level Rise Scenarios for Vietnam, Ministry of Natural Resources and Environment: Hanoi, Vietnam

Sartori, D. 2014 Guide to Cost-Benefit Analysis of Investment Projects, European Union, Italy

Solomon, S., D. Qin, M. Manning, Z. Chen, M. Marquis, K.B. Averyt, M. Tignor and H.L. Miller 2007 IPCC Fourth Assessment Report of the Intergovernmental Panel on Climate Change: The Physical Science of Climate Change, Cambridge University Press, Cambridge, United Kingdom and New York, USA

Tinh, B.D, N.V. Toan and T.H. Tuan 2013 Mangrove Restoration or Aquaculture Development: Cost and Benefit Analysis in Thi Nai Lagoon, Binh Dinh Province, The conference paper of the sixth Vietnam Economist Annual Meeting (VEAM 2013) at Hue city

Truong, D.D., 2011 Valuing the Total Economic Values of Wetlands in Ba Lat Estuaries, Nam Dinh province (Doctoral Dissertation). National Economics University, Hanoi, Vietnam

Tuan, T.H, T. Phong, K. Hawley, F. Khan and M. Moench 2015 Quantitative Cost - Benefit Analysis for Typhoon Resilient Housing in Da Nang City, Viet Nam. Urban Climate. 12 85-103

Tuan, T.H. and S. Navrud 2008 Capturing The Benefits of Preserving Cultural Heritage. Journal of Cultural Heritage $\mathbf{9}$ (3): 326-337 